DOI: 10.15503/onis2011-189-200

\title{
STOSUNKI TRANSATLANTYCKIE ZA PREZydenta G. W. BuSHA
}

\author{
Mateusz Lange \\ lange.mateusz@gmail.com
}

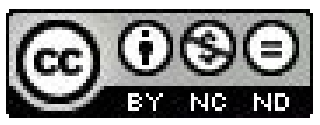

Stosunki między Stanami Zjednoczonymi a Europą po upadku ZSRR układały się pomyślnie dla obu stron. Świadczyć o tym mogą szczególnie zawarte porozumienia między stronami, jak choćby: Deklaracja Transatlantycka, Nowa Agenda Transatlantycka i Wspólny Plan Działania, które miały dać odpowiedź uczestnikom transatlantyzmu na temat stanu tych relacji wraz z wejściem w XXI wiek. Doskonałym ku temu sprawdzianem okazała się prezydentura Georgéa W. Busha i jego polityka zagraniczna, która po dzień dzisiejszy stanowi przedmiot wielu badań nad kondycją współpracy Stanów Zjednoczonych z Unią Europejską oraz perspektyw dalszego partnerstwa.

\section{BUSH PREZYDENTEM}

Listopadowe wybory prezydenckie w Stanach Zjednoczonych w 2000 r. przeszły do historii jako najbardziej burzliwe i kontrowersyjne. Onajwyższe stanowisko w państwie ubiegał się członek Partii Demokratycznej, wiceprezydent za rządów Billa Clintona, Albert Gore (vel. Al Gore), oraz republikański kandydat George Walker Bush - syn George'a Busha, byłego prezydenta USA w latach 1989-1993' Pomimo uzyskania przez Gore'a większego poparcia w wyborach powszechnych, zwycięzcą w wyniku głosów Kolegium Elektorów okazał się jednak Bush. Wybór republikanina na urząd prezydenta podzielił opinię publiczną nie tylko w Stanach Zjednoczonych, ale również w Europie. Wśród tych ostatnich wygrana Busha nie spotkała się z aprobata, wręcz przeciwnie - można było dostrzec pewne rozczarowanie i brak entuzjazmu. Wynikać to mogło między innymi z przykrych doświadczeń będących następstwem urzędowania już wcześniej republikańskich prezydentów - Ronalda Reagana, Georgéa Busha. W swoich politykach zagranicznych kierowali się przede wszystkim realizmem i unilateralizmem, co niejednokrotnie miało negatywny wpływ na Europę.

Wraz z przejęciem władzy przez George'a W. Busha, nikomu z jego najbliższego otoczenia nie przyszło do głowy, że prezydent pod wpływem wydarzeń z 11. września tak diametralnie zmieni swoje nastawienie zarówno do państwa, jak i świata. Zanim jednak to się stało, Bush w swoich pierwszych przemówieniach i wystąpieniach, nie koncentrował się na „osi zła”, „upadłych państwach” czy „,szerzeniu demokracji”. Wręcz przeciwnie, zależało mu przede wszystkim na polityce wewnętrznej państwa, a szczególnie: gospodarce, służbie zdrowia i deficycie, zgodnie z hasłem „najpierw Ameryka”². Tym samym starał się zaprezentować swoją osobę amerykańskiemu społeczeństwu, znanego ze swych izolacjonistycznych poglądów, jako tę niechętną wysyłaniu amerykańskich żołnierzy poza granice kraju i angażowaniu się amerykańskiego rządu w sprawy innych państw. Zauważyć tu można aluzję do byłego prezydenta Billa Clintona, któremu zarzucał brak jasno określonych priorytetów w polityce zagranicznej i bezpodstawne wysyłanie wojsk USA do różnych zakątków świata. Dlatego też, Bush przy każdej nadarzającej się okazji z pogardą odnosił się do swojego poprzednika. Postępował przy tym według założeń „,anything but not Clinton” (wszystko, byle nie Clinton)3. Wedle tej koncepcji, Bush w polityce zagranicznej obrał ogólny cel, w przeciwieństwie do Clintona. Najważniejszym zadaniem

1 P. Matera, R. Matera, Stany Zjednoczone i Europa. Stosunki polityczne i gospodarcze, Warszawa 2007, s. 362.

2 D. Eggert, Przewartościowania w stosunkach transatlantyckich w dziedzinie bezpieczeństwa w czasie prezydentury George'a W. Busha, "Stosunki Międzynarodowe" 2004, nr 3-4, s. 116.

3 I. H. Daalader, J. M. Lindsay, Ameryka bez ograniczeń. Rewolucja Busha w polityce zagranicznej, Warszawa 2005, s. 50. 
dla Busha było zabezpieczenie żywotnych interesów Stanów Zjednoczonych i nie angażowanie wojsk amerykańskich wszędzie tam, gdzie byłyby one w jakikolwiek sposób zagrożone. Zapowiedział przy tym, że przy ich przezwyciężaniu, istotną rolę odgrywać będą relacje z ich partnerami, ponieważ „prezydent Ameryki powinien współpracować z (...) sojusznikami w Europie i Azji dla utrwalenia pokoju. Powinien rozwijać pełną demokrację na Półkuli Zachodniej (...). Powinien bronić wszystkich amerykańskich interesów w Zatoce Perskiej i zaprowadzić pokój na Bliskim Wschodzie, w oparciu o zasadę bezpieczeństwa Izraela. Musi zapobiegać postępującemu rozprzestrzenianiu się broni masowego rażenia oraz środków jej przenoszenia" ${ }^{\prime \prime}$. Mimo tych zapewnień, stronę europejską bardziej zaniepokoiło oświadczenie na temat polityki zagranicznej Busha, jeszcze przed objęciem przez niego stanowiska prezydenta. W publicznym wystąieniu oznajmił, iż Stany Zjednoczone zamierzają powrócić do wzmocnienia relacji ze swoimi najbliższymi sąsiadami -Kanadą i Meksykiem, a także Ameryką Łacińską. Tego rodzaju zapowiedź przyszłej głowy państwa, nie mogła zostać bez odpowiedzi Europy. Brak skonkretyzowanych ram współpracy mógł odbić się niekorzystnie na kondycji ich partnerstwa. Choć prezydent $\mathrm{w}$ oficjalnych rozmowach nadal podtrzymywał dotychczasowy kierunek amerykańskiej dyplomacji wobec europejkkich sojuszników. Na co dowodami mogłoby być poparcie dalszej integracji UE, jej poszerzenia o kolejne państwa oraz tworzenia europejskiej polityki bezpieczeństwa i obrony, czy stanowisko rządu USA wobec wzmacniania i otwarcia Sojuszu Północnoatlantyckiego na nowych członków. To co dało się jednak zaobserwować, to fakt, że za kadencji G. W. Busha, doszło do pewnych przewartościowań między tymi dwoma sojusznikami, co kumulowało się już od początku lat 90.5 USA z „zimnej wojny" wyszły jako jedyny zwycięzca, kreując przy tym swoją rolę i pozycję w międzynarodowej strukturze w postaci ",hiperpotęgi" ${ }^{\prime \prime}$, której dotychczasowe relacje ze strategicznymi partnerami utraciły znaczenie, również w przypadku Europy. Tym samym nastało przeświadczenie wśród samych Amerykanów o ich wyjątkowości i samowystarczalności. Ponadto na Stary Kontynent zaczęto spoglądaćjak na słabszego sprzymierzeńca, który pogrążony w polityczne i gospodarcze konflikty, nie jest w stanie sprostać wymaganiom Stanów Zjednoczonych w przewodzeniu światem.

Zauważyć więc trzeba, że amerykańska polityka zagraniczna za prezydentury George'a W. Busha w jego pierwszych miesiącach urzędowania, diametralnie się zmieniła i odcięła od ówczesnych założeń administracji. W dodatku Ivo H. Daalder i James M. Lindsay zwracają uwagę na to, że obecna działalność polityczna Busha „,zrewolucjonizowała” się do tego stopnia, iż zerwała z bieżącą podstawą ukształtowaną po II wojnie światowej, a opartą głównie na tworzeniu sojuszy i międzynarodowych instytucji. Konsekwencją tego było zapewnienie Stanom Zjednoczonym bezpieczeństwo i zabezpieczenie narodowych interesów ${ }^{7}$. Należałoby $\mathrm{w}$ takim razie zastanowić się nad tym, co było bezpośrednią przyczyną zrewidowania ponad 50-letniej koncepcji w polityce zagranicznej, która w większości oparta była na willsonowskim stylu myślenia i nieangażowaniu, oraz zmiany charakteru sprawowania rządów przez Georgéa W. Busha. W tym przypadku pożądane byłoby przyjrzenie się bliżej współpracownikom administracji Busha zajmującym najwyższe stanowiska $\mathrm{w}$ państwie. Administracja ta bowiem, jak pokazuje historia, odgrywa znaczącą rolę w kształtowaniu idei polityki jako całości, a w szczególności polityki zagranicznej kraju przez oficjalne czy nieformalne wypowiedzi, dokumenty.

Neokonserwatyści, ponieważ to oni stanowili człon rządu Busha, początkowo w prawyborach poparli Johna McCaina na kandydata Partii Republikańskiej do Białego Domu. Twierdzili, że bli-

4 Tamże, s. 52.

T. Paszewski, Stosunki transatlantyckie z perspektywy amerykańskiej, „Sprawy Międzynarodowe” 2004, nr 4, s. 14

Pojęcie sformułowanie przez francuskiego ministra spraw zagranicznych Huberta Vedrine'a.

I. H. Daalader, J. M. Lindsay, Ameryka bez ograniczeń..., dz. cyt., s. 22. 
żej im do realistycznego światopoglądu McCaina niż tradycjonalisty Busha. Jednak nieoczekiwane zwycięstwo George'a W. Busha zadecydowało ostatecznie o zrewidowaniu swojego nastawienia do byłego gubernatora Teksasu i udzielenie mu wsparcia w ostatniej drodze do najważniejszego urzędu w państwie w walce z Alem Gore, Widzieli w nim równocześnie kontynuatora polityki Ronalda Reagana. Wygrana Busha umożliwiła neokonserwatystom ponowny powrót do amerykańskiej polityki po ponad dziesięcioletniej przerwie i to od razu piastując główne urzędy w państwie. Jednocześnie mając przy tym znaczący wpływ na charakter polityki zagranicznej. W tym samym czasie w gronie doradców prezydenta Busha dużego znaczenia nabrała nakreślona przez Paula Wolfowitza w 1992 r. koncepcja amerykańskiej strategii o nazwie Defense Planning Guidance. W jej założeniach chodziło przede wszystkim o „zapobieganie pojawieniu się konkurencyjnego mocarstwa, zabezpieczeniu interesów USA (...), gotowości do podjęcia jednostronnych działań prewencyjnych w sytuacji, gdy do akcji nie da się pozyskać sojuszników"s. Natomiast jej rozwinięcia podjął się utworzony przez neokonserwatystów 3. czerwca $1997 \mathrm{r}$. think-tank o nazwie Project for the New American Century9. Jego prace przyczyniły się do określenia czterech podstawowych postulatów, którym Stany Zjednoczone powinny sprostać $\mathrm{w}$ XXI wieku, jeśli nadal chcą myśleć o pozycji mocarstwa na arenie międzynarodowej. Do tych zaleceń zalicza się szczególnie: 1) zwiększenie wydatków na obronę i modernizację sił zbrojnych; 2) wzmocnienie współpracy ze strategicznymi partnerami i przeciwstawienie się wrogim państwom, których polityka zagraża interesom zarówno narodowym, jak i sojuszników USA; 3) propagowanie idei wolności ekonomicznej i politycznej oraz 4) wzięcie większej odpowiedzialności za bezpieczeństwo świata i partnerów USA ${ }^{10}$. Wybór doświadczonych polityków z ruchu neokonserwatywnego wynikał również w dużej mierze z ograniczonej wiedzy G. W. Busha na temat amerykańskiej racji stanu, a szczególnie relacji w stosunkach międzynarodowych. Dlatego Bush pragnąc przywrócić świetność i potęgę Stanów Zjednoczonych, o której pisał Charles Krauthammer w artykule The Unipolar Moment ${ }^{11}$ na łamach „Foreign Affairs”, stworzył grupę doradców określanej mianem „,wulkanu"12. Toteż sprawiło, że amerykańska polityka zagraniczna zaczęła uciekać w stronę unilateralnego postrzegania świata, bowiem w nowo powstałym gabinecie, większość stanowili „,jastrzę̨ie”, z którymi Bush sympatyzował. Doskonałym przykładem tej „bushowskiej rewolucji” w stosunkach międzynarodowych, a przy tym realizacji neokonserwatywnej wizji, okazało się odstąpienie strony amerykańskiej od następujących układów międzynarodowych: Międzynarodowego Trybunału Karnego, na rzecz bilateralnych porozumień z poszczególnymi państwami, co uchroni amerykańskich żołnierzy od odpowiedzialności przed tą instytucja, oraz zakazie broni biologicznej i stosowania min przeciwpiechotnych ${ }^{13}$. Jednak najwięcej kontrowersii, głównie państw Unii Europejskiej, wywołały jednostronne działania administracji Busha dotyczące porozumienia o ograniczeniu systemów obrony przeciwrakietowej $\mathrm{ABM}$ i redukcji emisji gazów cieplarnianych ${ }^{14}$.

Unilateralny charakter decyzji podjętych $w$ tym czasie przez G. W. Busha i realizowanie pewnych zadań w polityce zagranicznej na ich podstawie, sprawiło że w Unii Europejskiej, a szczególnie polityce Francji, Niemiec i po części Wielkiej Brytanii, niechętnie spoglądano na strategicznego sojusznika po drugiej stronie Atlantyku. W dodatku politycy wysuwali oznaki wielkiego rozczarowania i oburzenia, jakie było w przypadku wyżej wymienionych układów międzyna-

\footnotetext{
W. Szymborski, Doktryna Busha, Bydgoszcz 2004, s. 67.

Project for the New American Century, http://www.newamericancentury.org/aboutpnac.htm, 11.01.2010.

M. Troszyńska, Polityka zagraniczna Stanów Zjednoczonych w latach 2000-2004, Toruń 2006, s. 49.

C.Krauthammer, The Unipolar Moment, „Foreign Affairs” Winter 1990/1991, no. 1.

I. H. Daalader, J. M. Lindsay, Ameryka bez ograniczeń..., dz. cyt., s. 32.

J. Stachura, Meandry europejskiej polityki USA, „Studia Europejskie” 2004, nr 3, s. 36.

M. Troszyńska, Polityka zagraniczna Stanów Zjednoczonych..., dz. cyt., s. 51-55.
} 
rodowych. Zmianę nastrojów w relacjach transatlantyckich zauważył także sam prezydent. Stąd też z początkiem czerwca 2001 r., postanowił udać się w służbową podróż do Europy w celu naprawienia nadszarpniętej współpracy. Jego wizycie towarzyszyły liczne demonstracje w stolicach państw członkowskich Unii Europejskiej. Większość manifestujących sprzeciwiała się polityce zagranicznej realizowanej przez Busha. Jednak nie wpłynęło to negatywnie na dalsze relacje między USA a Starym Kontynentem. Pomimo rozbieżności w poglądach i podejściu do niektórych spraw natury międzynarodowej, można było mówić jedynie o pewnym kryzysie, a nie upadku, czy rozłamie. Jak się później okazało, atak terrorystyczny na Nowy Jork i Pentagon 11. września 2001 r. przysłonił wszystkie sprzeczności, z którymi do tej pory borykały się obie strony. Co więcej, potwierdził zasadność i moc partnerstwa transatlantyckiego.

\section{DoKTRYNa Busha}

Zamach terrorystyczny na Nowy Jork i Pentagon z dnia 11. września 2001 r., który pochłonął ok. 3000 ofiar, byłnie pierwszym tego rodzaju atakiem w historii Stanów Zjednoczonych. Jednakże żaden z nich nie był tak znaczący w skutkach dla nich samych i świata. Mam tu na myśli przede wszystkim ilość ofiar, które zginęły pod zgliszczami wież World Trade Center, oraz konsekwencje dla przyszłego funkcjonowania USA, jak i ich relacji z aktorami stosunków międzynarodowych. Stany Zjednoczone uświadomiły sobie, że bariera ochronna jaką do tej pory tworzył Ocean Atlantycki, jest niewystarczająca, a wyznawane dotychczas przez nią demokratyczne i liberalne wartości stały się nieaktualne. Ponadto USA jako jeden z głównych propagatorów globalizacji, zdało sobie sprawę, że we współczesnym świecie powiązanym wieloma nićmi współzależności, nie jest bezpieczne. Wielu publicystów i naukowców zgodnie twierdzi, że atak terrorystyczny z 11. września stał się dla Amerykanów ważną data, która otwiera nowy rozdział w ich historii. Idąc dalej tym wątkiem, Jacek Czaputowicz uważa, że XXI wiek dla Stanów Zjednoczonych „zaczął się 11. września $2001 \mathrm{r}$. atakiem na World Trade Center"15. Wydarzenie z 11. września odbiło się natychmiastową reakcją światowej opinii, w szczególności przez Unię Europejska. W kilka godzin po zamachu, przedstawiciele Unii Europejskiej wyrazili słowa współczucia i złożyli deklaracje solidarności ze Stanami Zjednoczonymi ${ }^{16}$. Następnego dnia, 12. września, Przewodniczący Komisji Europejskiej, Romano Prodi, oświadczył, że „Unia uczyni wszystko, co w jej mocy, by zapewnić, że odpowiedzialni za te akty bestialstwa zostaną postawieni przed sądem i ukarani" ${ }^{\prime \prime 17}$. Dodatkowo Unia Europejska potwierdziła gotowość uczestnictwa, przy boku Stanów Zjednoczonych, w schwytaniu sprawców odpowiedzialnych za to wydarzenie, a dzień 14. stycznia 2001 r. ustanowiła dniem żałoby w całej UE - ku czci ofiar ${ }^{18}$. Poza tym Unia postanowiła, że pomimo jej udziału w koalicji antyterrorystycznej, powinna również w sposób czynny prowadzić walkę z tym zagrożeniem asymetrycznym. Chodziło głównie o stworzenie jednej definicji terroryzmu i ustanowienie tzw. europejskiego nakazu aresztowania (European arrest warrant $)^{19}$.

15 A. Zdrada, Multilateralizm w polityce Stanów Zjednoczonych po 11 września. Rzeczywistość czy mit? , „Polska w Euro-

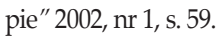

16 D. Eggert, Przewartościowania w stosunkach transatlantyckich..., dz. cyt., s. 118.

17 P. Turczyński, Wspólna Polityka Zagraniczna i Bezpieczeństwa UE, Wrocław 2007, s. 50; Zob. szerzej: Statement by Romano Prodi, President of the European Commission on the Terrorist Attacks on the United States, Bruksela, 12.09.2001, http:// www.deljpn.ec.europa.eu/home/news_en_newsobj670.php, 12.03.2010.

18 Joint Declaration on the Terrorist Attacks on the United States, Bruksela, 14.09.2001, http://www.deljpn.ec.europa.eu/ home/news_en_newsobj668.php, 12.03.2010.

19 Europe must have common instruments to tackle terrorism, Bruksela, 19.09.2001, http://europa.eu/rapid/pressReleasesAction.do?reference=IP/01/1284\&format=HTML\&aged=0\&langu,age=EN\&guiLanguage=en, 12.03.2011. 
Zaobserwować więc można, że rzekomy kryzys a co dopiero upadek czy rozłam, w stosunkach transatlantyckich nie był prawdą. Doskonałym tego dowodem jest postawa Unii Europejskiej wobec Stanów Zjednoczonych na tle wydarzeń z 11. września 2001 r. Potwierdziła się trwałość wartości demokratycznych, choć może nie do końca wspólnych celów, na których oparto partnerstwo między USA a Europą. Jednak w tym najtrudniejszym czasie dla Stanów Zjednoczonych, „wszyscy byli Amerykanami”. Równocześnie G. W. Bush wystąił z pierwszą odezwą telewizyjną do narodu pogrążonego w smutku. Stwierdzil, że „będziemy jednakowo traktować zarówno tych, którzy zaplanowali te zamachy, jak i tych, którzy udzielają terrorystom schronienia"20. Oznaczało to, że Stany Zjednoczone przystąpiły do walki z dotąd jeszcze niezidentyfikowanym wrogiem. Stanowiło to więc pewne odstępstwo od tradycyjnego rozumienia wojny i ataku. Mamy bowiem do czynienia ze zjawiskiem dotychczas niespotykanym. Oto wojska amerykańskie mają wziąć udział $\mathrm{w}$ walce z przeciwnikiem, który nie ma ściśle nakreślonych granic i nie posiada struktur państwowych. Obraz tego stanu doskonale przedstawił Henry Kissinger, który zauważył, że „nigdy dotąd nie trzeba było prowadzić wojen bez frontów ani geograficznych definicji i jednocześnie odbudowywać podstawowych zasad światowego ładu w miejsce tych tradycyjnych, które rozwiały się z dymem pogorzeliska World Trade Center Pentagonu"21. Zarówno Bush, jak i jego najbliższe otoczenie spodziewało się tego, że wojna, w której przyszło Amerykanom brać udział, będzie długa i wymagająca. Jednak prezydent postanowił przystąpić do niej. W tym też celu G. W. Bush wystosował kilka istotnych przemówień, które miały za zadanie przedstawić obywatelom powód wszczęcia działań wojennych. Ich następstwem było sformułowanie doktryny Busha. Do tych przemówień, które w sposób szczególny podkreślają charakter, konstrukcję $\mathrm{i}$ amerykański punkt widzenia $\mathrm{w}$ walce $\mathrm{z}$ terroryzmem, zalicza się przede wszystkim: wystąpienie prezydenta transmitowane z miejsca ataku, przemowę Busha do obu izb Kongresu (20. września 2001 r.), orędzie o stanie państwa (29. września 2002 r.), mowę prezydenta do kadetów ostatniego roku Akademii Wojskowej w West Point (01. września 2002 r.) oraz uwagi Busha na temat Bliskiego Wschodu (24. września 2002 r.) ${ }^{22}$. Natomiast ostateczna konceptualizacja polityki George'a W. Busha została w pełni zaprezentowana w dokumencie Narodowa Strategia Bezpieczeństwa USA z 17. września 2002 r. Doskonale oddaje on charakter wyżej wymienionych przemówień, $\mathrm{w}$ których fundamentalne wytyczne amerykańskiej polityki zagranicznej odpowiadały ideom wyznawanym przez neokonserwatystów. Na dodatek analizując z osobna każdą wypowiedź prezydenta i Narodowa Strategię Bezpieczeństwa USA, można by skłonić się do wyznaczenia głównych filarów doktryny Busha, sformułowanych na ich podstawie. Większość publicystów jest zgodna co do tego, że podstawowymi wyznacznikami nowej koncepcji polityki zagranicznej G. W. Busha sa: 1) mesjanizm; 2) unilateralizm jako wyróżnik hegemonii; 3) militaryzm oraz 4) działanie prewencyjne ${ }^{23}$.

20 W. Szymborski, Irak: casus belli, „,Sprawy Międzynarodowe” 2003, nr 2, s. 40.

${ }^{21}$ H. Kissinger, Dyplomacja w świecie dżihadu, „,Rzeczpospolita” 31.12.2004-02.01.2005, s. 14.

22 J. Bryła, Doktryna George'a Busha źródtem rozłamu w stosunkach transatlantyckich, „Przegląd Zachodni” 2005, nr 4, s. 36.

23 Z. J. Pietraś, Doktryna Busha a struktura systemu międzynarodowego, "Sprawy Międzynarodowe” 2004, nr 3, s. 12 16; Jadwiga Stachura w swojej analizie dotyczącej elementów doktryny Busha, wymienia jeszcze „koalicję chętnych" jako narzędzie współdziałania z innymi państwami oraz możliwość zawierania przez Stany Zjednoczone bilateralnych lub regionalnych umów. J. Stachura, Stany Zjednoczone jako supermocarstwo, "Sprawy Międzynarodowe” 2006, nr 4, s. 34-35. Dodatkowo do tej listy, John Ikenberry dokłada jeszcze upadek znaczenia międzynarodowego prawa, traktatów i instytucji regionalnych różnego typu oraz przeświadczenie o tym, że jedynie Stany Zjednoczone są w stanie sprostać dzisiejszym zagrożeniom. J. Ikenberry, America's Imperial Ambition „,Foreign Affairs” 2002, no. 48, s. 49-55. 


\begin{abstract}
Afganistan
George W. Bush do momentu zamachów z 11. września 2001 r. nie przywiązywał dużej uwagi do problemów politycznych i ekonomicznych poszczególnych regionów świata, w których Stany Zjednoczone miały narodowe interesy. Mogło to wynikać, jak już wiadomo, z niewiedzy Busha, czy małym zainteresowaniem polityką zagraniczną. Zmieniło się to jednak wraz z atakiem terrorystycznym. W Stanach Zjednoczonych rozgorzała debata na temat wojny z globalnym terroryzmem i zasięgiem tego konfliktu. Podstawą do jej realizacji była doktryna Busha, która w całości dotyczyła walki $\mathrm{z}$ tym nowym zagrożeniem dla bezpieczeństwa ładu światowego. Cechowała się przede wszystkim unilateralizmem i militaryzmem. Tego rodzaju podejścia amerykańskiej administracji do walki z terroryzmem nie podzielali sojusznicy Stanów Zjednoczonych, a zwłaszcza Unia Europejska. Różniło ich przede wszystkim stanowisko traktowania światowego terroryzmu. Unia Europejska do ataku z 11. września, choć strasznego w skutkach, podchodziła z dystansem ${ }^{24}$. W sumie uznała go za akt agresji dokonany na jej partnerze, ale nie godziła się na utworzenie koalicji celem zorganizowania krucjaty przeciw grupom terrorystycznym. Zdecydowana większość amerykańskiej opinii publicznej jest zgodna co do tego, że negatywne nastawienie UE do wojny z terroryzmem wynika głównie z propagowania przez Amerykanów sity w polityce zagranicznej jako narzędzia stabilizacji i demokratyzacjij ${ }^{25}$. Te odmienne nastawienia Stanów Zjednoczonych i Unii Europejskiej do zwalczania tego typu zagrożenia asymetrycznego przy użyciu komponentów siłowych nie wpłynęły na ich wzajemne stosunki. Unijni przedstawiciele jako pierwsi zareagowali na to wydarzenie, łącząc się w bólu i cierpieniu z Amerykanami. Zaproponowali im również natychmiastową pomoc w schwytaniu osób odpowiedzialnych za ten akt. Doskonałym sprawdzianem wspólnoty atlantyckiej okazał się Afganistan, w którym ukrywał się Osama bin Laden wraz z członkami Al - Kaidy. Pomimo udzielonego wsparcia w schwytaniu terrorystów na terytorium Afganistanu, kraje członkowskie UE sprzeciwiały się rozszerzeniu konfliktu na inne państwa leżące $\mathrm{w}$ jego sąsiedztwie. Toteż nie chciały prowadzenia działań antyterrorystycznych $\mathrm{w}$ krajach, które nie miały nic wspólnego z zamachami. Tym samym państwa Unii Europejskiej opowiadały sięjedynie za walką z Talibami i Al-Kaida, a nie „wojną z terroryzmem” jako taką. Ponadto strona unijna domagała się prowadzenia działańjedynie pod egidą ONZi za zgodą Rady Bezpieczeństwa ONZ, na co jednak początkowo nie chcieli zgodzić się Amerykanie.

Mimo zaistniałych sporów na tle wojny w Afganistanie, stosunki transatlantyckie w początkowej jej fazie kształtowały się na partnerskiej płaszczyźnie. Zarówno Unia Europejska, jak i Stany Zjednoczone osiagnęly to, czego chciały. Zbrojna interwencja w Afganistanie uzyskała prawną podstawę w postaci rezolucji RB ONZ, za którą optowała UE. Natomiast USA otrzymało międzynarodową zgodę i wsparcie na prowadzenie walki z globalnym terroryzmem, co było fundamentalnym założeniem doktryny Busha i administracji Stanów Zjednoczonych.

Wojna pod kryptonimem Trwała Wolność (Enduring Freedom) rozpoczęła się w Afganistanie 7. października 2001 r. atakiem bombowym z powietrza. Wymagała pomocy sił specjalnych wspótpracujących z Sojuszem Północnoatlantyckim przy odpieraniu i eliminowaniu ofensywy Talibów ${ }^{26}$.W początkowej fazie kampanii kraje Unii Europejskiej nie wzięły bezpośredniego udziału. Jedynie następnego dnia, 8. października 2001 r., Rada ds. Ogólnych wydała oświadczenie, które popierało działania Stanów Zjednoczonych w Afganistanie. Unia ogłosiła udzielenie pomocy humanitarnej obywatelom Afganistanu i przekazanie pewnej sumy pieniędzy na odbudowę kraju. Postawa Unii Europejskiej nie wpłynęła niekorzystnie na przebieg działań zbrojnych w Afganista-
\end{abstract}

24 J. Kiwerska, Światowe przywództwo USA, „Przegląd Zachodni” 2003, nr 3, s. 28.

25 Zob. szerzej: R. Kagan, Potęga i Raj. Ameryka i Europa w nowym porządku świata, Warszawa 2003.

26 S. Koziej, Między piekłem a rajem. Szare bezpieczeństwo na progu XX wieku, Toruń 2006, s. 178. 
nie. W dość szybkim czasie wojskom Stanów Zjednoczonych, jak i Paktu Północnoatlantyckiego ${ }^{27}$ udało się oponować znaczną część terytorium Afganistanu, uwalniając przy tym kraj spod rządów talibów i przyczyniając się do ich ucieczki na górskie tereny pogranicza pakistańsko-afgańskiego $0^{28}$.

Casus Afganistanu i problemy USA z nim związane negatywnie odbiły się na stosunkach transatlantyckich. Miało na to wpływ kilka czynników. Po pierwsze, państwa Unii Europejskiej deklarując współpracę ze Stanami Zjednoczonymi w walce z terroryzmem, nie wysłały swoich oddziałów do Afganistanu. Jedynie Wielka Brytania okazała się lojalnym partnerem USA i postanowiła oddać swoje oddziały wojskowe pod amerykańskie dowództwo. Przyczyniło się to do tego, że Stany Zjednoczone zwracając się do Unii Europejskiej o wsparcie, traktowały ją jak „,skrzynkę z narzędziami”. Dobierały tylko te państwa członkowskie, które w danej sprawie były najbardziej potrzebne i zawierały z nimi bilateralne porozumienia. Po drugie, Amerykanie doskonale zdawali sobie sprawę ze słabości militarnej UE oraz kwestii, że najważniejsze decyzje w sprawie obronności i bezpieczeństwa Unii zapadają w triumwiracie trzech państw: Francji, Niemiec i Wielkiej Brytanii. Po trzecie, Unia Europejska z niepokojem spoglądała na amerykańskie plany likwidacji reżimów państw „osi zła”. Dotyczyło to szczególnie kwestii Iraku, bowiem coraz częściej z Białego Domu dochodziły informacje o planowanej przez wojska amerykańskie inwazji na ten kraj. Po czwarte, państwa członkowskie UE krytycznie odnosiły się do bezprawnego przetrzymywania Afgańczyków w więzieniu w Guantanamo ${ }^{29}$.

Wyżej wymienione wydarzenia spowodowały, że relacje między Stanami Zjednoczonymi a Europą na rok przed atakiem na Irak, nie wyglądały najlepiej, co doskonale zobrazowała druga wojna w Zatoce Perskiej.

\section{IRAK}

Sprawa ataku na Irak była już wcześniej przesądzona, ale Bush ciaggle wstrzymywał się z inwazją z powodu braku dowodów. Kiedy było już jasne, że sytuacja w Afganistanie jest na tyle stabilna, że Stany Zjednoczone mogą pozwolić sobie na rozpoczęcie drugiej wojny, administracja poszukiwała mocnych argumentów przemawiających za wojną. Ostatecznie przyjęto, na co rząd rzekomo posiadał niezaprzeczalne dowody, że Saddam Hussein prowadzi nielegalne prace nad stworzeniem broni masowego rażenia, której w przyszłości nie zawaha się użyć przeciwko Stanom Zjednoczonym ${ }^{30}$. Co więcej, współodpowiedzialnym za zamachy z 11. września 2001 r. jest on sam. Miał niby spotykać się z Osamą bin Ladenem i pomóc mu w ich przygotowaniu ${ }^{31}$. Oile znalezienie dowodów potwierdzających słuszność ataku nie było trudne, to inaczej sprawa wyglądała ze strategią samej walki. Naprzeciw siebie stanęły dwie grupy neokonserwatystów o odmiennych opcjach ${ }^{32}$.

${ }^{27}$ Jedynym państwem Unii Europejskiej, który wniósł faktycznie militarny wkład w kampanię afgańską była Wielka Brytania. Zaś pozostałe państwa UE ograniczyły się jedynie do współpracy z USA w kwestii wywiadu i przesłaniu małych oddziałów wojskowych.

28 S. Tanner, Wojny Bushów. Ojciec i syn jako zwierzchnicy sił zbroinych, Wrocław 2007, s. 186.

29 Zob. szerzej: J. Foks, Status prawny członków Al-Qaidy oraz talibów osadzonych w Guantanamo, „Biuletyn” 2002, nr 66.

30 T. Kisielewski, Imperium Americanum. Międzynarodowe uwarunkowania sprawowania hegemonii, Warszawa 2004, s. 65-78.

31 Tamże, s. 79-94.

32 W. Szymborski, Irak: casus belli..., dz. cyt., s. 46. Z jednej strony ,jastrzębie” (Rumsfeld, Wolfowitz, Cheney), którzy za wszelką cenę dążyli do przeprowadzenia istotnych zmian na Bliskim Wschodzie i zniesienia reżimu Husseina, nawet w jednostronnej interwencji. Natomiast z drugiej strony "gołębie" (Colin Powell), dla których atak na Irak był równie oczywisty jak dla „jastrzębi”. Popierali jednak pozyskanie w tym działaniu międzynarodowego uznania, a szczególnie organizacji - odrzucali myśl o samotnej interwencji wojsk amerykańskich. 
Unia Europejska zdając sobie sprawę z faktu, że atak na Irak jest przesądzony, rozpoczęła własne działania w tej sprawie. Świadczyć o tym mogły chociażby przemówienia prezydenta Busha, w których porównywał terrorystów do krajów „osi zła”, jak i niedoszłe spekulacje Donalda Rumsfelda dotyczące udzielenia pomocy Osamie bin Ladenowi przez Irak w jego rzekomej ucieczce z Afganistanu. Tym razem unijni urzędnicy nie chcieli powtórki z początku kampanii afgańskiej, podczas której nie wszystkie państwa zastosowały się do unijnego stanowiska. Europa była przeciwna rozszerzeniu walki z terroryzmem na inne państwa Bliskiego Wschodu. Natomiast, jeśli miałoby już dojść do takiego ataku, to tylko za zgodą i poparciem ONZ. To jednak nie przeszkodziło Bushowi uzyskać 11. października 2002 r. pełnej zgody Kongresu na użycie wojska przez Stany Zjednoczone wobec Iraku, nawet gdyby interwencja nie miała zgody Rady Bezpieczeństwa ${ }^{33}$. Ta sytuacja diametralnie zmieniła stanowisko poszczególnych państw Unii Europejskiej, widzących stanowczość i nieustępliwość amerykańskiej administracji odnośnie Iraku. Zbrojny atak poparły m.in. Wielka Brytania, Hiszpania i Włochy. Natomiast Francja i Niemcy kategorycznie odcięły się od tego pomysłu, szukając rozwiązani na drodze dyplomatyczneje $j^{34}$. Ostatecznym rezultatem tego był sukces w postaci rezolucji nr 1441. Na jej podstawie określono ścisły harmonogram i tryb prac inspektorów Międzynarodowej Agencji Energii Atomowej (MAEA). Dodatkowo rezolucja potwierdzała, że jeśli Irak podejmie się pogwałcenia jakichkolwiek jej zobowiązań, to będą mu grozić ",poważne konsekwencje” ${ }^{\prime 35}$. Równolegle do prac wysłanników MAEA w Iraku, Stany Zjednoczone prowadziły zaciętą agitację wśród państw europejskich w celu uzyskania ich poparcia dla amerykańskich działań w Zatoce Perskiej. Z jednej strony były Wielka Brytania, Hiszpania, Włochy, Holandia i Dania, które opowiedziały się za USA. Natomiast na przeciwległym biegunie obecna była Francja i Niemcy, choć i oni nie mieli wspólnego stanowiska odnośnie Iraku. Niemcy jednoznacznie odcięły się od poparcia amerykańskiej polityki wobec Iraku $u^{36}$. W dodatku kanclerzowi Niemiec nie podobał się styl prowadzonej przez Busha taktyki, a przede wszystkim jego próbom narzucenia na sojuszników jednostronnych rozwiązan ${ }^{37}$. To zadecydowało o tym, że Niemcy nie wyraziły zgody na uczestnictwo w kampanii irackiej, także w razie objęcia jej mandatem $\mathrm{ONZ}^{38}$. Tymczasem Francja chcąc odgrywać ważną rolę $\mathrm{w}$ świecie, poparła udział wojsk francuskich w Iraku, ale jedynie pod egidą ONZ. Tym samym stała się również orędownikiem stworzenia tzw. frontu odmowy ${ }^{39}$ (Niemcy, Rosja, Francja), którego zadaniem było wykreowanie grup państw, przeciwstawiających się Stanom Zjednoczonym, jak i amerykańskiej polityce wobec Iraku.

Oprócz tych krajów, które opowiedziały się przeciwko amerykańskiej interwencji w Iraku, można wymienić jeszcze jeden blok państw, popierających amerykańskie stanowisko $\mathrm{w}$ walce z Husseinem. 30. stycznia 2003 r. osiem krajów, w tym pięć członków Unii Europejskiej: Wielka Brytania, Włochy, Hiszpania, Portugalia, Dania oraz trzy państwa kandydujące: Polska, Węgry, Czechy, podpisały deklarację wsparcia dla działań USA. Akt ten obecnie znany jako List 8, wy-

\footnotetext{
33 P. Milewski, Z tarcza strzelnicza na plecach, „Tygodnik Powszechny” grudzień 2001, nr 49, s. 3.

34 T. Kisielewski, Imperium Americanum..., dz. cyt., s. 219-220.

35 R. Kuźniar, Polityka i siła. Studia strategiczne - zarys problematyki, Warszawa 2005, s. 298.

36 E. Cziomer, Główne tendencje i problemu wielostronnej wspótpracy politycznej w nowej Europie, [w:] S. Parzymies, R. Zięba (red.), Instytucjonalizacja wielostronnej wspótpracy międzynarodowej w Europie, Warszawa 2004, s. 26.

37 Tamże, s. 27.

38 C. McArdle Kelleher, Irak - co dalej? Europa i Stany Zjednoczone w XXI wieku, [w:] R. Kuźniar, Z. Zachowski (red.), Bezpieczeństwo międzynarodowe czasu przemian, Warszawa 2003, s. 324.

${ }^{39}$ J. Kiwerska, Osamotnione supermocarstwo w świecie zagrożeń, „Przegląd Zachodni” 2005, nr 1, s. 32.
} 
wołał wielkie zamieszanie i poruszenie wewnątrz Unii Europejskiej ${ }^{40}$. Podobnie postąpiła grupa dziesięciu państw Europy Środkowo-Wschodniej, tzw. „grupa wileńska" ${ }^{\prime 41}$, która w podobnym tonie wystosowała odpowiedni list do rządu USA ${ }^{42}$.

Administracja Busha widząc rozłam wewnątrz Unii Europejskiej, który tak naprawdę sama spowodowała, parła dalej do przodu w kwestii ataku na Irak, zdobywając przy tym coraz to większe poparcie dla swoich działań. Punktem kulminacyjnym, który sprawił, że sprawa inwazji na Irak stała się już przesądzona, było wystąpienie 5. lutego 2003 r. sekretarza stanu Colina Powella na forum Rady Bezpieczeństwa ONZ. Celem jego przybycia, było przedstawienie dowodów na posiadanie przez Irak broni masowego rażenia ${ }^{43}$. Tymczasem w miesiąc po wystąieniu Powella w Radzie Bezpieczeństwa ONZ, 19. marca 2003 r. George W. Bush w przemówieniu telewizyjnym do narodu zapowiedział rozpoczęcie zbrojnych działań przeciw dyktatorskiej władzy Saddama Husseina w Iraku ${ }^{44}$. Wskutek tego z 19. na 20. marca sprzymierzone siły zapoczątkowały operację pod kryptonimem Iracka Wolność (Iraq Freedom). Działanie militarne przeprowadzono w błyskawicznym tempie, o czym świadczy choćby zajęcie w przeciągu $25 \mathrm{dni}$ od rozpoczęcia ataku, Bagdadu ${ }^{45}$. Po tym triumfie i oficjalnym zakończeniu działań wojennych, rozpoczął się okres „,normalizacji” i stabilizacji. Zapoczątkował go George W. Bush, który 1. maja 2003 r. wylądował na pokładzie lotniskowca USS Abraham Lincoln i oświadczył „mission acomplished" ${ }^{\prime \prime 6}$, co miało potwierdzić zakończenie zbrojnych działań w ramach inwazji na Irak.

Po wstępnym przeszukaniu miejsc możliwego składowania irackiej broni masowego rażenia okazało się, że Hussein jej nie posiadał, co więcej, w ostatnich kilku miesiącach poprzedzających amerykański atak, na terytorium Iraku, nie były prowadzone żadne badania w celu uzyskania wzbogaconego uranu, który mógłby być później wykorzystany do produkcji broni masowego rażenia ${ }^{47}$. Reżim Husseina nie miał także nic wspólnego z atakiem terrorystycznym z 11. września 2001 r. Potwierdzily się zatem nieoficjalne przyczyny rozpoczęcia kampanii: kontrola irackich pól naftowych, uzyskanie władzy nad jednym z największych zasobów energetycznych na świecie. $\mathrm{W}$ dodatku kryzys iracki miał również negatywne implikacje międzynarodowe ${ }^{48}$. Jednym $\mathrm{z}$ nich była destabilizacja w funkcjonowaniu ONZ, bowiem organizacja nie zdołała w żaden sposób wymusićna jej członkach przestrzegania rezolucji 1441 i zapobiec ich udziałowi w interwencji zbrojnej na Bliskim Wschodzie. To samo dotyczy Sojuszu Północnoatlantyckiego, który został potraktowany przez Stany Zjednoczone jak „,skrzynka z narzędziami”" ${ }^{49}$, uzewnętrzniając zresztą jego słabość

40 Zob. szerzej: T. Kisielewski, Imperium Americanum..., dz. cyt., s. 225-226; Zob. szerzej: C. Saint-Étienne, Potęga albo śmierć. Europa wobec imperium amerykańskiego, Warszawa 2004, s. 87-95; P. Matera, R. Matera, Transatlantyckie rozbieżności w dobie wojny z terroryzmem, "Sprawy Międzynarodowe” 2004, nr 1, s. 40-43.

${ }_{41}$ Grupę tych państw tworzyła: Litwa, Łotwa, Estonia, Bułgaria, Rumunia, Słowacja, Słowenia, Albania, Chorwacja i Macedonia.

${ }^{42}$ J. Bielecki, Dziesiątka dołacza do ósemki, „Rzeczpospolita” 06.02.2003, s. 3.

43 M. Lasoń, Interwencja zbrojna w Iraku jako czynnik destabilizujacy stosunki międzynarodowe na poczatku XXI wieku, [w] I. Stawowy-Kawka (red.), Czynniki stabilizacji i destabilizacji w stosunkach międzynarodowych na początku XXI wieku, Kraków 2009, s. 372.

44 Zob. szerzej: President Bush Addresses the Nation, http://georgewbush-whitehouse.archives.gov/news/releases/2003/03/20030319-17.html, 03.03.2010.

45 W. Ostant, Zwalczanie terroryzmu we wspótczesnym świecie, „Przegląd Zachodni” 2006, nr 4, s. 193.

46 S. Tanner, Wojny Bushów..., dz. cyt., s. 250.

47 C. Fuentes, Contra Bush, Warszawa 2005, s. 120

48 R. Kuźniar, Polityka i siła ..., dz. cyt., s. 302.

49 Inaczej „tool-box". Koncepcja sformułowana przez Donalda Rumsfelda. Jej celem było wywarcie na poszczególnych państwach członkowskich NATO przeprowadzenie specjalizacji militarnej, aby Stany Zjednoczone w ramach „koalicji chętnych” mogły dobierać odpowiednie zdolności dla danego rodzaju operacji. 
i brak przystosowania do zagrożeń współczesnego świata. Jednakże najbardziej widocznym następstwem drugiej wojny w Iraku było załamanie się stosunków transatlantyckich, które w całej swojej historii istnienia nie były aż tak złe.

Przystępując do oceny polityki zagranicznej George'a W. Busha i jej wpływu na stosunki z Europą można zauważyć, że republikański prezydent przyczynił się do naruszenia i osłabnięcia współpracy transatlantyckiej, która tak mozolnie była budowana od czasu zjednoczenia Niemiec. Zastąienie polityki „soft power" przez "hard power" doprowadziło do reinterpretacji wzajemnych relacji i pojawienia się pytania: co dalej z partnerstwem? W tym problemie, jakim jest określenie wspólnych celów i interesów, na którym miałyby opierać się przyszłe stosunki, oraz co jest prawdziwym spoiwem ich więzi, oprócz wartości demokratycznych, można doszukać się drugiej głębi, która mogłaby stać się fundamentem pod zdefiniowanie ich sojuszu. Chodzi o to, że zarówno sprawa Afganistanu, jak i Iraku uwypukliła pewne słabości, z którymi borykają się obie strony. Nadmierna wiara w swoją wyjątkowość i możliwość rozwiązania wszystkich konfliktów za pomocą siły, doprowadziły Stany Zjednoczone do tego stanu, jaki widać obecnie. Brak planu wyjścia z Afganistanu i przywrócenie tam stabilizacji, okazały się dla USA trudnym zadaniem, co tylko podważyło ich wiarygodność w świecie. Natomiast dwie wojny w rejonie Bliskiego Wschodu wykazały słabość Unii w podejmowaniu decyzji i udziału w nich europejskiego komponentu wojskowego. Brak logistycznych i technologicznych instrumentów w przeprowadzaniu działań wojennych przez Unię Europejską oraz niedobór cywilnych zdolności Stanów Zjednoczonych, powinien zmusić obie strony do znalezienia odpowiedniej płaszczyzny, na której można by rozpocząć proces ponownego definiowania wzajemnych relacji. Najlepszym obszarem takiej współpracy mogłaby być Organizacja Paktu Północnoatlantyckiego. To właśnie na jej podstawie powinien zostać stworzony nowy mechanizm konsultacji wspólnych celów i interesów. Wykorzystanie przez USA swojego potencjału militarnego, a przez Unię Europejską zasobów cywilnych, mogłoby w przyszłości doprowadzić do powstania dwóch równorzędnych partnerów w stosunkach międzynarodowych. Natomiast za pomocą wyżej wymienionych specjalizacji i wspólnie wyznawanych wartości, mogliby odpowiadać za kreowanie równowagi w świecie.

\section{BibLIOGRAFIA}

Bielecki J., Dziesiątka dołacza do ósemki, „Rzeczpospolita”, 06.02.2003.

Bryła J., Doktryna George'a Busha źródłem rozłamu w stosunkach transatlantyckich, „Przegląd Zachodni” 2005, nr 4.

Cziomer E., Główne tendencje i problemu wielostronnej wspótpracy politycznej w nowej Europie, [w:] Parzymies S., Zięba R. (red.), Instytucjonalizacja wielostronnej wspótpracy międzynarodowej w Europie, Warszawa 2004.

Daalader I. H., Lindsay J. M., Ameryka bez ograniczeń. Rewolucja Busha w polityce zagranicznej, Warszawa 2005.

Eggert D., Przewartościowania w stosunkach transatlantyckich w dziedzinie bezpieczeństwa w czasie prezydentury George'a W. Busha, "Stosunki Międzynarodowe" 2004, nr 3-4.

Foks J., Status prawny członków Al-Qaidy oraz talibów osadzonych w Guantanamo, „Biuletyn” 2002, nr 66.

Fuentes C., Contra Bush, Warszawa 2005.

Ikenberry J., America's Imperial Ambition, „Foreign Affairs” 2002, no. 48.

Kagan R., Potęga i raj. Ameryka i Europa w nowym porzadku świata, Warszawa 2003.

Kisielewski T., Imperium Americanum. Międzynarodowe uwarunkowania sprawowania hegemonii, Warszawa 2004.

Kissinger H., Dyplomacja w świecie dżihadu, „Rzeczpospolita” 31.12.2004-02.01.2005.

Kiwerska J., Osamotnione supermocarstwo w świecie zagrożeń, „Przegląd Zachodni” 2005, nr 1.

Kiwerska J., Światowe przywództwo USA, „Przegląd Zachodni” 2003, nr 3.

Koziej S., Między piekłem a rajem. Szare bezpieczeństwo na progu XX wieku, Toruń 2006. 
Krauthammer C., The Unipolar Moment, "Foreign Affairs” Winter 1990/1991, no. 1.

Kuźniar R., Polityka i siła. Studia strategiczne - zarys problematyki, Warszawa 2005.

Lasoń M., Interwencja zbroina w Iraku jako czynnik destabilizujacy stosunki międzynarodowe na poczatku XXI wieku, [w] Stawowy-

-Kawka I. (red.), Czynniki stabilizacji i destabilizacji w stosunkach międzynarodowych na początku XXI wieku, Kraków 2009.

Matera P., Matera R., Stany Zjednoczone i Europa. Stosunki polityczne i gospodarcze, Warszawa 2007.

Matera P., Matera R., Transatlantyckie rozbieżności w dobie wojny z terroryzmem, „Sprawy Międzynarodowe” 2004, nr 1.

McArdle Kelleher C., Irak - co dalej? Europa i Stany Zjednoczone w XXI wieku, [w:] Kuźniar R., Zachowski Z. (red.), Bezpieczeństwo międzynarodowe czasu przemian, Warszawa 2003.

Milewski P., Z tarczą strzelniczą na plecach, „Tygodnik Powszechny” grudzień 2001, nr 49.

Ostant W., Zwalczanie terroryzmu we wspótczesnym świecie, „Przegląd Zachodni” 2006, nr 4.

Paszewski T., Stosunki transatlantyckie z perspektywy amerykańskiej, „Sprawy Międzynarodowe” 2004, nr 4.

Pietraś Z. J., Doktryna Busha a struktura systemu międzynarodowego, „Sprawy Międzynarodowe” 2004, nr 3.

Saint-Étienne C., Potęga albo śmierć. Europa wobec imperium amerykańskiego, Warszawa 2004.

Stachura J., Meandry europejskiej polityki USA, „Studia Europejskie” 2004, nr 3.

Stachura J., Stany Zjednoczone jako supermocarstwo, „Sprawy Międzynarodowe” 2006, nr 4.

Szymborski W., Doktryna Busha, Bydgoszcz 2004.

Szymborski W., Irak: casus belli, „Sprawy Międzynarodowe” 2003, nr 2.

Tanner S., Wojny Bushów. Ojciec i syn jako zwierzchnicy sił zbrojnych, Wrocław 2007.

Troszyńska M., Polityka zagraniczna Stanów Zjednoczonych w latach 2000-2004, Torun 2006.

Turczyński P., Wspólna Polityka Zagraniczna i Bezpieczeństwa UE, Wrocław 2007.

Zdrada A., Multilateralizm w polityce Stanów Zjednoczonych po 11 września. Rzeczywistość czy mit?, „Polska w Europie” $2002, \mathrm{nr} 1$.

\section{Netografia}

Europe must have common instruments to tackle terrorism, Bruksela, 19.09.2001, http://europa.eu/rapid/pressReleasesAction. do?reference=IP/01/1284\&format=HTML\&aged=0\&langu, age=EN\&guiLanguage=en, 12.03.2010.

Joint Declaration on the Terrorist Attacks on the United States, Bruksela, 14.09.2001, http://www.deljpn.ec.europa.eu/home/ news_en_newsobj668.php, 12.03.2010.

President Bush Addresses the Nation,

http://georgewbush-whitehouse.archives.gov/news/releases/2003/03/20030319-17.html, 03.03.2010.

Project for the New American Century, http://www.newamericancentury.org/aboutpnac.htm, 11.01.2010.

\section{Słowa kluczowe}

doktryna Busha, wojna z terroryzmem, wojna w Iraku.

\section{STRESZCZENIE}

Głównym celem niniejszego artykułu jest przybliżenie odbiorcy stanu stosunków transatlantyckich za prezydenta G. W. Busha. Mam tu na myśli przede wszystkim wpływ amerykańskiej głowy państwa na polityczną i ideologiczną współpracę między Stanami Zjednoczonymi a Europą oraz ich wzajemnego kontaktu z międzynarodowym środowiskiem.

Stosunki transatlantyckie mają długą historię. W zależności od panującego prezydenta Stanów Zjednoczonych, przybierały różną formę. USA pod rządami George'a H. W. Busha nawiązały formalny amerykańsko-unijny dialog dzięki Deklaracji Transatlantyckiej z 1990 r.. Natomiast politycznej istoty nadała jej dopiero Nowa Agenda Transatlantycka z 1995 r. za rządów administracji Clintona. Tymczasem wydarzenia z $2001 \mathrm{r}$. dokonały rewolucyjnych zmian w partnerstwie transatlantyckim, których skutki we wzajemnych relacjach odczuwane są po dzień dzisiejszy.

Celem tego artykułu jest więc przedstawienie wzajemnych stosunków USA i Europy w trakcie rządów G. W. Busha. Poprzez ten artykuł udzielam również odpowiedzi na następujące wątki problemowe:

- Polityka zagraniczna USA i relacje z Europą przed atakami z 11 września.

- Atak terrorystyczny i reakcja administracji Busha (Doktryna Busha) - odpowiedź Europy. 
- Kryzys we wzajemnych relacjach - wojna w Afganistanie i Iraku.

- Nowe wyzwania dla partnerstwa transatlantyckiego.

\section{TransatLantic ReLATIONS IN THE TIMES OF THE PRESIDENT G. W. BuSH}

\section{Keywords}

Bush doctrine, war on terrorism, war in Iraq

\section{Summary}

The main aim of this article is a presentation of transatlantic relations in the times of G. W. Bush. By transatlantic relations I mean above all the influence of American president on political and ideological cooperation between The United States and Europe and their reciprocal contact with international environment.

Transatlantic relations have a long history. Depending on the reigning president of The United States they have taken different shapes. Thanks to Transatlantic Declaration from 1990 the USA started a formal American-European Union dialogue under the reign of George H. W. Bush. However, it gained a serious political meaning as late as in 1995 with New Transatlantic Agenda signed in the times of Clinton's administration. Mean-while, the events of year 2001 contributed to revolutionary changes in transatlantic partnership. Their consequences in reciprocal transatlantic relations have been experienced up to now.

Consequently, the aim of this article is a presentation of mutual relations between the USA and Europe during the reign of G. W. Bush. In this work I would like also to describe the following issues:

- Foreign policy of the USA and relations with Europe before the attacks from September 11.

- Terroristic attack and the reaction of Bush's administration (Bush Doctrine) - the Europe's answer.

- The crisis in reciprocal transatlantic relations - wars in Afghanistan and Iraq.

- New challenges for transatlantic partnership. 